\title{
ANALYZING THE EFFECT OF INCOME INEQUALITY ON ECONOMIC GROWTH
}

\author{
Gourang Goyal \\ Satyawati College, University of Delhi \\ DOI: 10.46609/IJSSER.2021.v06i06.008 URL: https://doi.org/10.46609/IJSSER.2021.v06i06.008
}

\begin{abstract}
There has been a common assumption that inequality and growth have a negative relationship that is when inequality decreases growth increases and vice-versa. This paper aims to examine the effect of income inequality on economic growth and test the common assumption using simple and multiple regression analysis. The study was conducted using data from 74 countries from the year 2011. Previous literature has produced mixed results, with some research finding a positive correlation and some finding a negative correlation. The country's state of development was also considered as outlined by the dummy variable used in the analysis. The findings of this paper depict a positive relationship between inequality and growth according to the results of the regression analysis.
\end{abstract}

Keywords: Economic Growth, Income Inequality, Multiple Linear Regression, Simple Linear Regression

\section{Introduction}

At this point in time, income inequality is a topic that is very important to discuss. According to the International Monetary Fund, the global economy is predicted to grow by 5.5 percent in 2021 and 4.2 percent in 2022 (IMF, 2021). The growth in both developed and developing countries is predicted to rise gradually in 2021 due to the coronavirus pandemic that caused an economic crisis in 2020 but is expected to pick up in the further two years (IMF, 2021). However, there are some aspects that have to be addressed to achieve the desired growth, one of them is income inequality.

Growth is necessary. It generates employment, provides a better standard of living and increases the income of the nation. It is something that all people, government, and economies aim to achieve. On the other hand, inequality is very upsetting. Income inequality refers to disparities in the distribution of income, that is, the gap between the rich and the poor in a country. The 


\section{International Journal of Social Science and Economic Research}

ISSN: $2455-8834$

Volume:06, Issue:06 "June 2021"

primary effects of income inequality are that it hampers poverty reduction, leads to policies that hamper growth, reduces opportunities for the underprivileged (IMF Library). It is a problem that disrupts the balance within society.

It is important to analyze the relationship between income inequality and economic growth to find suitable policies and then implement them. If there exists a relationship between inequality and growth is very important to find the nature of that relationship. If they are negatively related then the obvious solution would be to increase growth and reduce inequality, but if there exists a positive relationship it may create a problem. The question that arises is how much inequality is acceptable to have economic growth or how much growth one must give up to have more equality. After analyzing various articles and literature this paper hypothesizes a negative relationship between income inequality and economic growth across countries, the aim of this paper is to test this hypothesis using data obtained from 74 countries from the year 2011.

Gini coefficient is chosen to measure income inequality in countries and GDP growth (annual \%) is chosen to measure economic growth.

This paper is organized as follows. Section 2 analyzes existing literature regarding the research to elaborate on the hypothesis that has been created. Section 3 introduces the data and explains the method used to conduct the study. Section 4 evaluates the results obtained from regression analysis, and Section 5 concludes the findings of the paper.

\section{Literature Review}

There exists an extensive literature on the relationship between economic growth and income inequality. The most relevant is considered to be the Kuznets Curve. It was presented by Simon Kuznets, who based his assumption on data from United States, England, and Germany. From the data, he came to the conclusion that there exists a relationship between inequality and growth which is similar to an inverted U-shaped curve. When a country's economy is in its early stages, the income inequality is higher when the economy grows, and when the economy will reach its final stage the income inequality will decrease as the economy grows.(Kuznets, 1955) Another study conducted by Robert J. Barro investigated this relationship in a panel of countries. He concludes in his study that the trend between income inequality and economic growth also depends on the income level of the country where the relationship is initially negative for developing countries and positive for developed countries. (Barro, 2000). However, this inverted U-shaped hypothesis has been challenged in many other studies. For instance, in study the conducted by Li, Square, and Zho (Li ,1998) it was suggested that this hypothesis is unconfirmed for less developed countries. The authors suggested that the increase in inequality was inevitable in the final stages of economic development, thus giving the appearance of a U-shaped curve and 


\section{International Journal of Social Science and Economic Research}

ISSN: $2455-8834$

Volume:06, Issue:06 "June 2021"

not the reverse as stated by Kuznets. Similarly, The hypothesis of an inverted U-curve between growth and inequality was likewise challenged by the work of Bowman (1997) who focused on a group of countries. Indeed, in Japan and Greece, the initial phases of development did not affect the level of inequality. For the author, the rapid development of South Korea and Taiwan was not accompanied by an increase in income inequality. Instead, it has decreased in Taiwan and stabilized in South Korea. Thus the Kuznets curve is insufficient to explain the relation between inequality and growth. It has been said that Kuznets neglects the effect of impact of other factors in the distribution of income.

Most of the theories concluded the relationship between inequality and growth to be negative but some researchers conclude that there exists a positive relationship between them, like the study conducted by KJ Forbes (Forbes, 2000). However, his study was criticized due to the very low number of observations. While some literature declares a positive relationship and others support a negative one, there are some studies in which no position is taken and both sides of the debate are examined and analyzed (Shin, 2012). Shin chose not to pursue a particular stance on the topic but rather chose to examine the reasons why this disparity exists. According to Shin, there is a correlation between the positive/negative relationship between inequality and economic growth and whether or not the country is developed or not. Shin performed a case study of East Asian and South American countries, which are developing countries. The findings revealed a negative relationship between income inequality and economic growth in those countries. Conversely, in a case study of the United States and France, which are developed countries, a positive relationship between income inequality and economic growth was found. The author concludes that the impact of income inequality will differ depending on development, which this paper will analyze further later on. The literature is largely divided on this topic, therefore the objective of this paper is to find the effect of income inequality on economic growth by analyzing the database obtained from various sources.

\section{Data and Method}

The primary objective of this paper is to test the relation between income inequality and economic growth. For the regression model GDP Growth Rate (annual \%) is chosen as dependent variable (Y) and the GINI coefficient has been used to measure inequality within a country and is chosen to be the independent variable $(\mathrm{X})$. Gini coefficient is chosen for this model because it is a common measure of income inequality across many countries that represents the income distribution of a country's residents, where 0 represents perfect equality and 100 represents absolute inequality. Gini coefficient is also used and mentioned in most of the literature that was analyzed. The data for GDP growth and GINI coefficient has been obtained from World Bank's data sets (World Bank Data Sheet). The data has been obtained for 74 


\section{International Journal of Social Science and Economic Research}

ISSN: $2455-8834$

Volume:06, Issue:06 "June 2021"

countries from the year 2011 .

For the simple linear regression model, the GINI coefficient was chosen as the primary explanatory variable and GDP growth was chosen as the primary dependant variable.

Multiple regression models were also formed to uncover the true ceteris paribus effect of the development of a country's inequality on economic growth. For the multiple linear regression model, various other independent variables were chosen such as; GDP per capita, Human Development Index (HDI), mean years of education, fertility rate and savings rate, scientific articles written in 2011 and unemployment rate.

Saving Rate (World Bank, 2011) was chosen because it shows a country's ability to consume and save, fertility rate(World Bank, 2011) was included because analyzed literature shows lower fertility leads to economic growth, Unemployment rate (World Bank, 2011) was chosen because it shows the economy is operating below full capacity and is inefficient; this will lead to lower output and incomes, GDP per capita (World Bank, 2011) shows how much production value can be divided between each citizen, mean years of schooling (United Nations Human Development Report, 2011) was chosen at it is considered that a higher education level would produce more skilled labour thus leading to higher growth and Human Development Index (United Nations Human Development Report, 2011) was included because it shows overall condition of citizens of the country and includes both social and economic dimension. Scientific articles written in 2011 (World Bank, 2011) are included to study the effect of technological factors on economic growth.

A negative relationship between GDP growth and Gini coefficient has been hypothesized initially. This hypothesis has been tested in the results section.

Table 1: Description of variables

\begin{tabular}{|l|l|}
\hline Variable name & Description \\
\hline gdpgr & GDP Growth (annual \%) \\
\hline gini & Gini Coefficient (World Bank estimate) \\
\hline svgrt & Saving rate (as a \% of GDP) \\
\hline frtrt & Fertility Rate \\
\hline gdppc & GDP per capita (according to 2010 \$) \\
\hline \hline
\end{tabular}


International Journal of Social Science and Economic Research

ISSN: 2455-8834

Volume:06, Issue:06 "June 2021"

\begin{tabular}{|l|l|}
\hline unmplt & Unemployment rate (\% of total labor force) \\
\hline hdi & Human Development Index \\
\hline meanedu & Mean years of schooling \\
\hline scntfart & Scientific articles written in 2011 \\
\hline devl & Developed (1) or developing (0) (dummy) \\
\hline
\end{tabular}

Table 2: Descriptive statistics for each variable

\begin{tabular}{|l|l|l|l|l|l|}
\hline Variable & Observation & Mean & $\begin{array}{l}\text { Standard } \\
\text { Deviation }\end{array}$ & Minimum & Maximum \\
\hline Gdpgr & 74 & 3.9899471 & 3.692738 & -9.132494 & 17.29077 \\
\hline Gini & 74 & 36.234666 & 7.86115 & 24.6 & 56.2 \\
\hline Svgrt & 74 & 21.30865 & 10.23542 & -2.46715 & 50.1021 \\
\hline Frtrt & 74 & 2.29278 & 1.21549 & 1.23 & 7.429 \\
\hline Gdpgc & 74 & 18331.65199 & 21884.407 & 417.603 & 105264.74 \\
\hline Unmplt & 74 & 8.2904 & 5.8173 & 0.32 & 31.3799 \\
\hline Hdi & 74 & 0.72566 & 0.13781 & 0.338 & 0.942 \\
\hline Meanedu & 74 & 9.22666 & 2.94762 & 1.5 & 13.8 \\
\hline Scntfart & 74 & 21606.626 & 63244.5 & 10.95 & 4238958.81 \\
\hline
\end{tabular}

The method of OLS (Ordinary Least Squared) estimation has been used to estimate the regression models, for amodel to be appropriate it must satisfy all the assumptions of Classical Linear Regression Model (CLRM).

- Both the models are Linear in Parameters (LIP); thus, the first assumption is satisfied. 
International Journal of Social Science and Economic Research

ISSN: 2455-8834

Volume:06, Issue:06 "June 2021"

- The value of population disturbance term $(\mu)$ is assumed to be 0 .

- All explanatory variables are uncorrelated with the error term.

- The error term has constant variance. (Homoscedasticity)

- Observations of the error term are uncorrelated with each other. (No Autocorrelation)

- No explanatory variable is a perfect linear function of any other explanatory variables (no perfect multicollinearity)

- Error should not be specified. (No specification biasedness)

\section{Results}

\section{Simple Linear Regression Model}

The purpose of the simple linear regression model is to test the relationship between GDP growth and the Gini coefficient. To test this relationship, GDP Growth was only regressed on the Gini coefficient. This was done to uncover the direct impact of increase or decrease in GINI coefficient will have on GDP growth.

Simple Regression Model 1: $g d p g r=\beta_{0}+\beta_{1}($ gini $)+\mu$

Results of regression analysis of model 1 are given below:

Table 3: OLS Simple Regression

\begin{tabular}{|l|l|l|l|l|l|}
\hline $\begin{array}{l}\text { Independent } \\
\text { Variable }\end{array}$ & Coefficient & $\begin{array}{l}\text { Standard } \\
\text { Error }\end{array}$ & t-value & P-value & $\mathrm{R}^{2}$ \\
\hline Constant & -1.01433 & 1.94783 & -0.52074 & 0.60411 & \\
\hline gini & 0.138107 & 0.05254 & 2.62813 & 0.010459 & 0.086439 \\
\hline
\end{tabular}

*Significant at $5 \%$

The model is significant because the p-value is 0.01 or t-value lies within the critical points range $(-1.666,1.666)$. Replacing the value of coefficients in model 1 we get:

Model 1: gdpgr $=-1.01433+0.138107($ gini $)+\mu$ 


\section{International Journal of Social Science and Economic Research}

ISSN: 2455-8834

Volume:06, Issue:06 "June 2021"

The results are contrary to the initial hypothesis that there exists a negative relationship between GDP growth and gini coefficient, in fact, there exists a positive relation between them. If Gini increases by 1 point, then GDP growth increases by 0.13 according to results. Also, the results show that if there is perfect equality (gini $=0$ ) then GDP growth will be -1.01 which reduces GDP.

The $\mathrm{R}^{2}$ is 0.086439 which indicates that Gini coefficient only explains $8.6 \%$ of GDP growth, therefore a multiple regression model is also built to better understand the relationship.

\section{Multiple Regression Model}

To make a more appropriate model and avoid any omission of variables a multiple regression model was also made, various other independent variables were added to this model, a dummy variable was also introduced (devl) to study the effect of state of development of the country on economic growth after considering Barrow's and Shin's theory. These variables have been mentioned in the data section of this paper. The multiple regression model is as follow:

Model 2: gdpgr $=\beta 0+\beta 1($ gini $)+\beta 2($ gdppc $)+\beta 3($ svgrt $)+\beta 4($ frtrt $)+\beta 5($ hdi $)+\beta 6($ meanedu $)+$ $\beta 7($ scntfart $)+\beta 8($ unmplt $)+\beta 9($ devl $)+\mu$

Table 4: OLS Multiple Regression

\begin{tabular}{|l|l|l|l|l|l|}
\hline $\begin{array}{l}\text { Independent } \\
\text { Variable }\end{array}$ & Coefficient & $\begin{array}{l}\text { Standard } \\
\text { Error }\end{array}$ & t-value & P-value & $\mathrm{R}^{2}$ \\
\hline Constant & 3.90990805 & 3.89178329 & 1.00465718 & 0.31878741 & \\
\hline Gini & 0.06546451 & 0.051854021 & 1.26247703 & 0.2112879 & $\mathbf{0 . 3 9 5 0 6 1 4 4}$ \\
\hline GDP per capita & -1.965 & 2.285 & -0.8597475 & 0.39308811 & \\
\hline Saving rate & 0.0263446 & 0.0369700 & 0.63928734 & 0.52488266 & \\
\hline Fertility rate & 0.322065 & 0.38971635 & 0.8264099 & 0.4115948 & \\
\hline HDI & -11.684293 & 4.28517386 & -2.726679 & 0.0082149 & \\
\hline Mean education & 0.495541 & 0.1828147 & 2.710623 & 0.008580 & \\
\hline $\begin{array}{l}\text { Scientific } \\
\text { articles }\end{array}$ & 1.834 & 5.9677 & 3.073291 & 0.003092 & \\
\hline
\end{tabular}


International Journal of Social Science and Economic Research

ISSN: 2455-8834

Volume:06, Issue:06 "June 2021"

\begin{tabular}{|l|l|l|l|l|l|}
\hline $\begin{array}{l}\text { Unemployment } \\
\text { rate }\end{array}$ & 0.137529 & 0.0641615 & 2.143491 & 0.035820 & \\
\hline $\begin{array}{l}\text { Developed or } \\
\text { developing }\end{array}$ & -1.076861 & 0.914360 & -1.177720 & 0.24320201 & \\
\hline
\end{tabular}

Testing the variables at 5\% and 1\% levels of significance with null hypothesis stating that coefficients are equal to zero and alternative hypothesis stating that coefficients are not equal to zero. The following table shows the significance of the variables. Two tailed tests were conducted for all the variables. The critical point for $5 \%$ and $1 \%$ level are $(-1.669,1.669)$ and ($2.386,2.386)$ respectively.

Table 5: Significance of variables

\begin{tabular}{|l|l|l|}
\hline Variable & Significance at 5\% & Significance at 1\% \\
\hline Constant & Significant & Significant \\
\hline Gini & Significant & Significant \\
\hline GDP per capita & Insignificant & Significant \\
\hline Saving rate & Significant & Significant \\
\hline Fertility rate & Significant & Significant \\
\hline HDI & Insignificant & Insignificant \\
\hline Mean education & Insignificant & Insignificant \\
\hline ICT import & Significant & Significant \\
\hline Scientific articles & Insignificant & Insignificant \\
\hline Unemployment rate & Insignificant & Significant \\
\hline Developed or developing & Significant & Significant \\
\hline
\end{tabular}

The model after replacing the value of coefficients is as follows:

Model 2: gdpgr $=3.9099+0.0654($ gini $)-1.965($ gdppc $)+0.02634($ svgrt $)+0.32206($ frtrt $)-$ 11.68429 (hdi) +0.49554 (meanedu) +1.834 (scntfart) +0.13752 (unmplt) $-1.076861($ devl $)+\mu$

Once again, the results are opposite to our initial hypothesis, there exists a positive relationship between economic growth and income inequality according to analysis. If there is absolute equality (gini=0) then growth will be 3.9099. If Gini increases by 1 point, then GDP growth increases by $6 \%$. With $1 \%$ increase in savings rate there is $2 \%$ increase in GDP growth this supports Shin's model that an increase in savings will increase economic growth. (Shin,2012). Fertility and economic growth are also positively related, $1 \%$ increase in fertility rate leads to 
International Journal of Social Science and Economic Research

ISSN: 2455-8834

Volume:06, Issue:06 "June 2021"

0.32 increase in economic growth, this can be due to an increase labor force that can increase productivity. GDP per capita, HDI, mean years of schooling and unemployment rate are insignificant variables to our model.

Thus, both simple and multiple regression models indicate that there exists a positive relationship between income inequality and economic growth.

\section{Robustness}

To check the joint impact of variables on economic growth, F-test was conducted. The null hypothesis states that coefficient of all independent variable equal 0 and alternative hypothesis stating that the at least one is greater than

Test statistics for F-test $\Rightarrow \mathrm{F}=4.716$. the critical value at $5 \%$ level of significance is 2.027 . Therefore, we reject the null hypothesis this implies that all independent variables have a joint effect on GDP growth.

\section{Conclusion}

The initial hypothesis that there exists negative relationship between GDP growth and incoming quality was not supported by the simple linear and multiple linear regression model in fact there exists so positive relationship between them. It is found that a $1 \%$ increase in Gini coefficient leads to GDP growth to increase by $6.5 \%$. This result not only challenges our initial hypothesis and supporting literature but also poses a serious issue.

The fact that GDP growth and income inequality are positively related is a troubling fact. If a nation wants to increase growth, then a direct implication of it will increase inequality. Similarly, if inequality has to be decreased it would be at the cost of economic growth. If the findings of this are true, one question that we face is how much inequality can be accepted in order to achieve growth. There is no definite answer to this question, we only found data on gini coefficient for 74 countries which means more countries need to accurately report inequality for better understanding of the topic and policy formation.

In conclusion, this has been a topic that has always been widely debated, further investigation is needed to find the exact nature of the relationship and achieve the optimal combination of economic growth and income inequality.

\section{References}

1. (IMF,2021) 
International Journal of Social Science and Economic Research

ISSN: 2455-8834

Volume:06, Issue:06 "June 2021"

https://www.imf.org/en/Publications/WEO/Issues/2021/01/26/2021-world-economic-outlookupdate

2. (IMF,2021)

https://www.imf.org/en/Publications/WEO/Issues/2021/01/26/2021-world-economic-outlookupdate

3. (IMF Library)

https://www.elibrary.imf.org/view/IMF006/22594-9781513555188/22594-

9781513555188/22594-9781513555188_A001.xml?language $=\mathrm{en}$

4. (Kuznets, 1995)

https://www.jstor.org/stable/1811581?seq=1

5. (Barro, 2000)

https://scholar.harvard.edu/files/barro/files/p inequalitygrw.pdf

6. (Li, 1998)

http://documents1.worldbank.org/curated/en/892521468762914086/pdf/multi0page.pdf

7. (Forbes, 2000)

https://www.aeaweb.org/articles?id=10.1257/aer.90.4.869

8. (Shin, 2012)

https://econpapers.repec.org/article/eeeecmode/v_3a29_3ay_3a2012_3ai_3a5_3ap_3a2049-

2057.htm

9. (World Bank, 2011)

https://databank.worldbank.org/indicator/NY.GDP.MKTP.KD.ZG/1ff4a498/Popular-Indicators

10. (United Nations Human Development Report, 2011)

http://www.hdr.undp.org/en/indicators/137506

\section{APPENDIX}

List of countries

Algeria Lebanon

Argentina Lithuania 


$\begin{array}{ll}\text { Armenia } & \text { Luxembourg } \\ \text { Austria } & \text { Malaysia } \\ \text { Belarus } & \text { Malta } \\ \text { Belgium } & \text { Moldova } \\ \text { Benin } & \text { Mongolia } \\ \text { Bolivia } & \text { Netherlands } \\ \text { Bosnia and Herzegovina } \quad \text { North Macedonia } \\ \text { Brazil } & \text { Niger } \\ \text { Bulgaria } & \text { Norway } \\ \text { China } & \text { Pakistan } \\ \text { Chile } & \text { Panama } \\ \text { Colombia } & \text { Peru } \\ \text { Congo, Rep. } & \text { Paraguay } \\ \text { Costa Rica } & \text { Poland } \\ \text { Croatia } & \text { Portugal } \\ \text { Cyprus } & \text { Romania }\end{array}$

Czech Republic Russian Federation

Denmark Senegal

Dominican Republic Sierra Leone

Ecuador Slovenia

El Salvador Slovak Republic

EstoniaSpain 


$\begin{array}{ll}\text { Finland } & \text { Switzerland } \\ \text { France } & \text { Sweden } \\ \text { Georgia } & \text { Tanzania } \\ \text { Germany } & \text { Thailand } \\ \text { Greece } & \text { Togo } \\ \text { Honduras } & \text { Turkey } \\ \text { Hungary } & \text { Ukraine } \\ \text { India } & \text { United Kingdom } \\ \text { Iceland } & \text { United States } \\ \text { Indonesia } & \text { Uruguay } \\ \text { Ireland West } & \text { Bank and Gaza } \\ \text { Italy } & \text { Zimbabwe }\end{array}$

Kazakhstan Kyrgyz Republic 


\section{International Journal of Social Science and Economic Research}

ISSN: 2455-8834

Volume:06, Issue:06 "June 2021"

\section{Table 6: Output summary for simple linear regression}

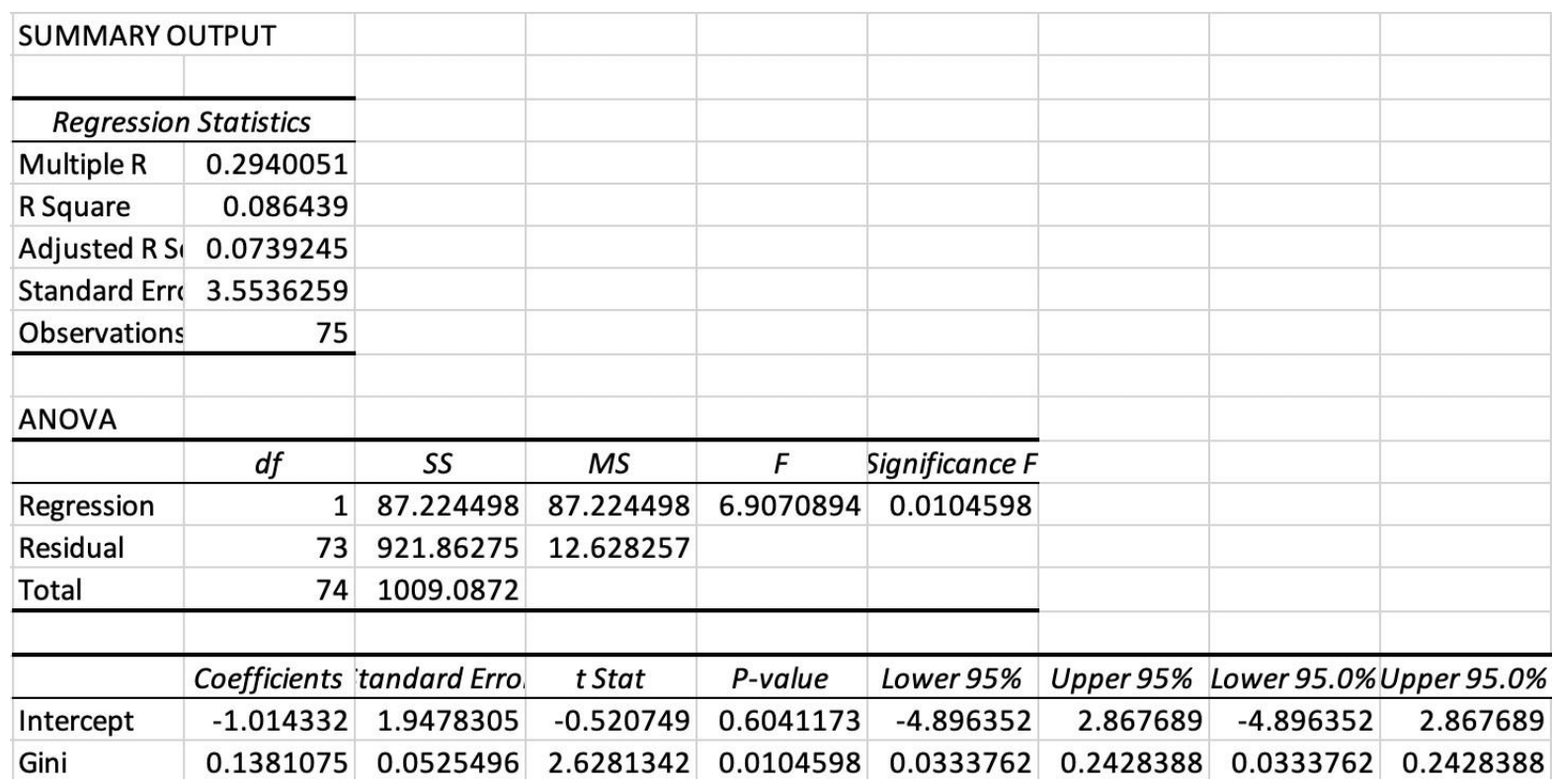

Table 7: Output summary for multiple linear regression

\begin{tabular}{|c|c|c|c|c|c|c|c|c|}
\hline \multicolumn{9}{|c|}{ SUMMARY OUTPUT } \\
\hline \multicolumn{9}{|c|}{ Regression Statistics } \\
\hline Multiple R & 0.62853913 & & & & & & & \\
\hline R Square & 0.39506144 & & & & & & & \\
\hline Adjusted R Sc & 0.31130072 & & & & & & & \\
\hline \multicolumn{9}{|c|}{ Standard Erri 3.06452602} \\
\hline \multicolumn{9}{|c|}{ Observations $\quad 75$} \\
\hline \multirow{2}{*}{\multicolumn{9}{|c|}{ ANOVA }} \\
\hline & & & & & & & & \\
\hline & $d f$ & SS & MS & $F$ & Significance $F$ & & & \\
\hline Regression & 9 & 398.6514627 & 44.294607 & 4.71654765 & $7.8078 \mathrm{E}-05$ & & & \\
\hline Residual & 65 & 610.4357822 & 9.39131973 & & & & & \\
\hline \multirow[t]{2}{*}{ Total } & 74 & 1009.087245 & & & & & & \\
\hline & Coefficients & Standard Error & $t$ Stat & $P$-value & Lower 95\% & Upper 95\% & Lower $95.0 \%$ & Upper $95.0 \%$ \\
\hline Intercept & 3.90990805 & 3.891783294 & 1.00465718 & 0.31878741 & -3.8625199 & 11.68233599 & -3.8625199 & 11.68233599 \\
\hline Gini & 0.06546451 & 0.051854021 & 1.26247703 & 0.2112879 & -0.038095121 & 0.169024143 & -0.0380951 & 0.169024143 \\
\hline GDP per capi & $-1.965 \mathrm{E}-05$ & $2.28531 E-05$ & -0.8597475 & 0.39308811 & $-6.52887 E-05$ & $2.59929 \mathrm{E}-05$ & $-6.529 E-05$ & 2.59929E-05 \\
\hline gross savings & 0.02363446 & 0.036970005 & 0.63928734 & 0.52488266 & -0.050199742 & 0.097468654 & -0.0501997 & 0.097468654 \\
\hline fertility rate & 0.32206547 & 0.389716354 & 0.82640995 & 0.41159487 & -0.456251832 & 1.100382776 & -0.4562518 & 1.100382776 \\
\hline hdi & -11.684294 & 4.285173862 & -2.726679 & 0.00821496 & -20.24237693 & -3.126210599 & -20.242377 & -3.126210599 \\
\hline mean educat & 0.49554188 & 0.182814734 & 2.71062332 & 0.00858011 & 0.130435646 & 0.860648117 & 0.13043565 & 0.860648117 \\
\hline articles & $1.834 \mathrm{E}-05$ & 5.9677E-06 & 3.07329184 & 0.00309252 & $6.42216 \mathrm{E}-06$ & $3.02588 \mathrm{E}-05$ & $6.4222 \mathrm{E}-06$ & $3.02588 \mathrm{E}-05$ \\
\hline unempl rate & 0.13752968 & 0.064161536 & 2.14349112 & 0.0358208 & 0.009390247 & 0.265669119 & 0.00939025 & 0.265669119 \\
\hline develped(1) c & ( -1.0768619 & 0.914360858 & -1.1777209 & 0.24320201 & -2.902966654 & 0.749242811 & -2.9029667 & 0.749242811 \\
\hline
\end{tabular}

